Vol.3 No.2 Hal. $69-77$

September 2020

\title{
Efek Pericarpium Manggis (Garcinia mangostana L.) Terhadap Protein Spermatozoa Epididimal Mencit Setelah Dipapar 2-Methoxyethanol
}

\author{
Putri Ayu Ika Setiyowati \\ Program Studi S1 Biologi, Fakultas Sains dan Teknologi, Universitas Muhammadiyah Lamongan \\ putriayuikasetiyowati@gmail.com
}

\begin{abstract}
ABSTRAK
Penelitian ini bertujuan untuk mengetahui pengaruh pemberian ekstrak fraksi pericarpium manggis (Garcinia mangostana L.) dengan variasi kepolaran dan dosis terhadap profil protein epididimal spermatozoa mencit (Mus musculus) yang terpapar 2-Methoxyethanol. Penelitian ini menggunakan 50 ekor mencit jantan strain BALB/C dengan berat badan 25-30 gram yang dibagi menjadi 8 kelompok; kelompok kontrol positif diberi $0,05 \mathrm{ml}$ larutan CMC 0,05 \% selama 40 hari , kelompok kontrol negatif diberi $200 \mathrm{mg} / \mathrm{kg}$ BB 2Methoxyethanol selama 35 hari, kelompok perlakuan (P1, P2, P3, P4, P5, dan P6) diberi 200 mg/kg BB 2Methoxyethanol selama 5 hari, dilanjutkan dengan pemberian ekstrak fraksi dan dosis, kelompok $\mathrm{P}_{1}$ dan $\mathrm{P}_{2}$ diberi ekstrak fraksi non polar pericarpium manggis dengan dosis $0,6 \mathrm{mg} / \mathrm{kg}$ BB dan $3 \mathrm{mg} / \mathrm{kg}$ BB selama 35 hari , $\mathrm{P}_{3}$ dan $\mathrm{P}_{4}$ diberi ekstrak fraksi semi polar dengan dosis $4 \mathrm{mg} / \mathrm{kg}$ BB dan $20 \mathrm{mg} / \mathrm{kg}$ BB selama 35 hari, $\mathrm{P}_{5}$ dan $\mathrm{P}_{6}$ diberi ekstrak fraksi polar pericarpium manggis dengan dosis $0,4 \mathrm{mg} / \mathrm{kg}$ BB dan $2 \mathrm{mg} / \mathrm{kg} \mathrm{BB}$ selama 35 hari. Protein diisolasi dari spermatozoa yang dikoleksi dari epididimis, kemudian diukur konsentrasinya dan dianalisis menggunakan elektroforesis SDS-PAGE. Data yang diperoleh dianalisis secara deskriptif dengan membandingkan profil protein kelompok kontrol dan kelompok perlakuan. Hasil penelitian menunjukkan bahwa ekstrak fraksi polar pericarpium manggis dengan dosis $0,4 \mathrm{mg} / \mathrm{kg} \mathrm{BB}$ dapat berpengaruh dalam memulihkan profil protein $(20 \mathrm{kDa})$ dari spermatozoa epididimal mencit setelah terpapar 2-Methoxyethanol.
\end{abstract}

Kata Kunci : Garcinia mangostana L., protein spermatozoa, spermatozoa epididimal, 2-Methoxyethanol.

\begin{abstract}
The aim of this study to know the effect of mangosteen pericarp extract fraction with polarity and dose variation on the protein profile epididymal spermatozoa of mice (Mus musculus) after exposed 2-Methoxyethanol. This study using animal model of 50 male mice strain BALB/C, weight 25-30 gram, divided into 8 groups; the positive control group was given $0,05 \mathrm{~mL}$ of $0,05 \% \mathrm{CMC}$ within 40 days, negative control group was given 2Methoxyethanol $200 \mathrm{mg} / \mathrm{kg}$ body weight within 5 days, treatment groups $\left(\mathrm{P}_{1}, \mathrm{P}_{2}, \mathrm{P}_{3}, \mathrm{P}_{4}, \mathrm{P}_{5}\right.$, and $\left.\mathrm{P}_{6}\right)$ were given 2-Methoxyethanol $200 \mathrm{mg} / \mathrm{kg}$ body weight within 5 days, continued by giving fraction extract and doses, $\mathrm{P}_{1}$ and $\mathrm{P}_{2}$ groups were given non polar fraction of mangosteen pericarp extract with doses $0,6 \mathrm{mg} / \mathrm{kg}$ body weight and $3 \mathrm{mg} / \mathrm{kg}$ body weight within 35 days, $\mathrm{P}_{3}$ and $\mathrm{P}_{4}$ groups was given semi polar fraction of mangosteen pericarp extract with doses $4 \mathrm{mg} / \mathrm{kg}$ body weight and $20 \mathrm{mg} / \mathrm{kg}$ body weight within 35 days, $\mathrm{P}_{5}$ and $\mathrm{P}_{6}$ groups was given polar fraction of mangosteen pericarp extract with doses $0,4 \mathrm{mg} / \mathrm{kg}$ body weight and $2 \mathrm{mg} / \mathrm{kg}$ body weight within 35 days. Proteins were isolated from epididymal spermatozoa then the concentration was measured and analyzed using SDS-PAGE electrophoresis. Data were analyzed descriptively by comparing the protein profile of control and the treatment group. The result showed that magosteen pericarp polar fraction extract with doses $0,4 \mathrm{mg} / \mathrm{kg}$ body weight influencial to recover protein profile $(20 \mathrm{kDa})$ from epididymal spermatozoa Mus musculus that exposoed by 2-Methoxyethanol.
\end{abstract}

Keywords : Garcinia mangostana L., spermatozoa protein, epididymal spermatozoa, 2- Methoxyethanol 
Setiyowati Putri Ayu I : Efek Pericarpium Manggis (Garcinia mangostana L.) Terhadap Protein Spermatozoa Epididimal Mencit Setelah Dipapar 2-Methoxyethanol

\section{PENDAHULUAN}

\section{Latar Belakang}

Indonesia merupakan Negara biodiversitas, yakni salah satunya adalah keanekaragaman tumbuhan (flora) yang berpotensi sebagai obat. Upaya pemanfaatan tanaman sebagai sumber suatu obat menjadi pilihan utama bagi para peneliti obat di Indonesia. Salah satu tanaman di Indonesia yang bisa dimanfaatkan untuk tujuan tersebut adalah buah manggis (Garcinia mangostana L.), terutama pemanfaatan pericarpiumnya (Fitri et al., 2017). Telah diketahui bahwa pericarpium manggis mengandung senyawa xanthone. Xanthone berfungsi sebagai antioksidan yaitu dengan cara menurunkan aktivitas radikal bebas (Kurniawati et al., 2014). Penelitian yang dilakukan oleh (Moongkarndi et al., 2004) telah menunjukkan dua senyawa mangostin $(\alpha$ dan $\gamma)$ serta garsinon-E pada ekstrak kulit buah manggis dalam dosis $(5 \mu \mathrm{g} / \mathrm{ml})$ dan $(10-20 \mu \mathrm{g} / \mathrm{ml})$ berfungsi sebagai antioksidan, namun pada dosis yang tinggi $(40 \mu \mathrm{g} / \mathrm{ml})$ menyebabkan apoptosis pada sel dikarenakan ketiga senyawa tersebut mampu meningkatkan kadar Reactive Oxygen Species (ROS) atau radikal bebas di dalam sel. Radikal bebas ini akan sangat berbahaya bagi beberapa organ salah satunya organ reproduksi yaitu dapat berpengaruh pada sintesis proteinnya. Salah satu protein yang sangat penting untuk berlangsungnya proses fertilisasi adalah protein spermatozoa khususnya pada organ epididimis, protein tersebut sangat peka terhadap radikal bebas (Gaudreault et al., 2001). Kehadiran radikal bebas karena peningkatan ROS dapat disebabkan oleh paparan bahan kimia yang bersifat toksik dan merupakan oksidan yang kuat, salah satunya 2Methoxyethanol (2- ME). Senyawa teratogenik ini terbentuk dari hasil hidrolisis metabolit dimethoxyethyl phthalate (DMEP), DMEP merupakan salah satu kelompok dari phthalic acid ester (PAEs) yang banyak digunakan sebagai pelentur dalam pembuatan plastik. Selain bersifat teratogenik DMEP dan turunannya, juga merupakan toksikan pada organ reproduksi terutama pada hewan jantan, dengan testis sebagai sasaran utamanya (Starek-wiechowicz et al., 2015). Sejauh ini telah banyak dilakukan penelitian tentang manfaat senyawa xanthone dan turunannya yang ada di crude (total keseluruhan) ekstrak pericarpium manggis, namun sepanjang pengetahuan penulis belum pernah ada penelitian yang menggunakan ekstrak fraksi pericarpium manggis terkait pengaruhnya terhadap protein spermatozoa, sehingga perlu dilakukan penelitian untuk mengetahui pengaruh ekstrak fraksi pericarpium manggis dengan berbagai tingkat kepolaran dan variasi dosis dalam upaya mendapatkan antioksidan yang efektif untuk memulihkan profil protein spermatozoa epididimal akibat paparan 2-ME.

\section{Perumusan Masalah}

Berdasarkan latar belakang di atas dapat dibuat rumusan masalah yaitu : Apakah pemberian ekstrak fraksi pericarpium manggis dengan variasi kepolaran dan dosis berpengaruh terhadap profil protein epididimal spermatozoa mencit?

\section{Tujuan Penelitian}

Tujuan dari penelitian ini adalah untuk mengetahui pengaruh pemberian variasi kepolaran dan dosis ekstrak fraksi pericarpium manggis terhadap profil protein epididimal spermatozoa mencit (Mus musculus) yang telah terpapar senyawa 2-ME.

\section{Manfaat Penelitian}

Penelitian ini diharapkan dapat memberikan informasi terkait tentang pengaruh pemberian variasi kepolaran dan dosis ekstrak fraksi pericarpium manggis terhadap profil protein epididimal spermatozoa mencit (Mus musculus) yang telah terpapar oksidan kuat senyawa 2-ME. 
Setiyowati Putri Ayu I : Efek Pericarpium Manggis (Garcinia mangostana L.) Terhadap Protein Spermatozoa Epididimal Mencit Setelah Dipapar 2-Methoxyethanol

\section{METODE PENELITIAN}

Metode penelitian ini menggunakan metode eksperimental laboratorik dengan tahapan penelitian yaitu, mengekstraksi pericarpium manggis, perlakuan terhadap hewan coba, mengisolasi spermatozoa epididimal mencit, elektroforesis protein spermatozoa epididimal, hingga analisis data. Analisis data yaitu dengan membandingkan profil protein hasil SDS PAGE pada masing-masing kelompok kontrol, dan perlakuan. Profil protein yang diamati berupa berat molekul $(\mathrm{BM})$. Perhitungan $\mathrm{BM}$ dari masing-masing protein dilakukan berdasarkan pada marker yang tersedia. Perhitungan dilakukan dengan mengukur jarak migrasi pita protein atau Retardation factor (Rf). Nilai Rf dihitung dengan menggunakan rumus (Mahasri et al., 2010).

$\mathrm{Rf}=\mathrm{x} 1 / \mathrm{x} 2$

$\mathrm{x} 1=$ Jarak pergerakan protein dari tempat awal

$\mathrm{x} 2=$ Jarak pergerakan warna dari tempat awal

Kemudian dari nilai Rf tersebut, dihitung log BM dari masing-masing BM pita marker. BM pita polipeptida pada sampel dihitung dengan persamaan linier:

$\mathrm{Y}=\mathrm{a} \pm \mathrm{bx}$

Nilai log BM sebagai sumbu x dan Rf sebagai sumbu Y.

\section{Alat dan Bahan Penelitian}

Alat yang digunakan berupa bak plastik dengan penutup dan botol minuman, alat-alat untuk perlakuan berupa berupa botol-botol kecil tempat larutan yang akan dicobakan, spuit $1 \mathrm{cc}$, jarum suntik, alat bedah, botol untuk membius, mikropipet, timbangan analitik, shaker, papan paraffin, jarum, cawan petri kecil, microtube, mikroskop inverted, blue tip, yellow tip, vortex, sentrifuge, plate, power supply, penangas, chamber elektroforesis, spektrofotometer, autoclave, rotary evaporator, dan alat destilasi. Bahan penelitian yang digunakan adalah hewan uji yaitu menggunakan mencit (Mus musculus) jantan 50 ekor, strain BALB/C, umur 8 -9 minggu, berat badan 25 - 30g, $\mathrm{n}$ - heksan, etil asetat, etanol, 2- ME, alkohol 70\%, untuk isolasi epididimial menggunakan larutan phosphate buffer saline (PBS), buffer lisis, es batu, dan akuades steril, separating gel. Stacking gel, Reducing Sampel Buffer (RSB), larutan staining dan destaining, buffer elektroforesis.

\section{Pelaksanaan Penelitian}

Fraksinasi variasi kepolaran fraksi dari kulit manggis

Proses fraksinasi ini dilakukan dengan menggunakan corong pisah untuk memisahkan senyawa-senyawa yang terkandung, dimulai dari senyawa non polar terlebih dahulu, dimasukkan n-heksan ke dalam toples kaca yang berisi berat kering pericarpium manggis, dilakukan pengocokan (dilakukan dengan cara diaduk setiap dua jam sekali selama tiga hari), kemudian fraksi n-heksan (bagian atas) ditampung. Hal ini dilakukan terus hingga fraksi nheksan tidak berwarna/ jernih. Setelah jernih, dilakukan pergantian pelarut dari n-heksan ke etil asetat, lalu dilakukan hal yang sama seperti n-heksan. Ketika fraksi etil asetat selesai maka dilakukan pergantian pelarut terakhir yaitu dari etil asetat (pelarut semi polar) ke etanol (pelarut polar).

\section{Perlakuan terhadap hewan coba}

Mencit (Mus musculus) yang telah diaklimatisasi pada kondisi kandang selama satu minggu, lalu dibagi menjadi delapan kelompok dengan masing-masing kelompok terdapat tujuh ekor mencit. Kelompok kontrol negatif diberi Carboxyl Methil Cellulosa (CMC) 0,05\% sebanyak $0,05 \mathrm{ml}$ selama 40 hari secara sub cutan. Kelompok kontrol positif, perlakuan pertama, perlaukan kedua, perlakuan ketiga, perlakuan keempat, perlakuan kelima dan perlakuan keenam diberi 2-ME dengan dosis $200 \mathrm{mg} / \mathrm{kg}$ BB setiap satu kali sehari selama lima hari. Kemudian kelompok kontrol positif dilakukan perlakuan Carboxyl Methil Cellulosa (CMC) $0,05 \%$ sebanyak $0,05 \mathrm{ml}$ selama 35 hari secara sub cutan. Pemberian larutan sebanyak 0,05 $\mathrm{ml}$ ini. Kelompok P1 dan P2 diberi fraksi non polar (n-heksan) pericarpium manggis dengan 
Setiyowati Putri Ayu I : Efek Pericarpium Manggis (Garcinia mangostana L.) Terhadap Protein Spermatozoa Epididimal Mencit Setelah Dipapar 2-Methoxyethanol

dosis rendah dan tinggi yaitu $0,6 \mathrm{mg} / \mathrm{kg}$ berat badan, dan $3 \mathrm{mg} / \mathrm{kg}$ berat badan yang dilarutkan dalam CMC 0,05\% sebanyak 0,05 ml, selama 35 hari secara sub-cutan. P3 dan $\mathrm{P} 4$ diberi fraksi semi polar (etil asetat) pericarpium manggis dengan dosis rendah dan tinggi yaitu $4 \mathrm{mg} / \mathrm{kg}$ berat badan, dan $20 \mathrm{mg} / \mathrm{kg}$ berat badan yang dilarutkan dalam CMC 0,05\% sebanyak 0,05 ml, selama 35 hari secara sub-cutan. P5 dan P6 diberi fraksi polar (methanol) pericarpium manggis dengan dosis rendah dan tinggi yaitu $0,4 \mathrm{mg} / \mathrm{kg}$ berat badan, dan 2 $\mathrm{mg} / \mathrm{kg}$ berat badan yang dilarutkan dalam CMC 0,05\% sebanyak 0,05 ml, selama 35 hari secara sub-cutan.

\section{Tahap isolasi spermatozoa epididimal mencit (Mus musculus)}

Metode isolasi protein spermatozoa epididimal mencit pada penelitian ini, yaitu yang pertama, koleksi spermatozoa yang telah diencerkan dengan larutan PBS pH 7,2, kemudian disentrifugasi pada kecepatan 3000 rpm selama 10 menit, diambil peletnya dan ditambahkan $70 \mu \mathrm{l}$ buffer ekstrak protein, lalu di vortex selama 10 menit untuk homogenisasi. Homogenate ini disentrifuse pada $6000 \mathrm{rpm}$ selama 15 menit. Supernatan yang didapatkan dipindahkan pada microtube yang baru, dan disimpan pada suhu $-20^{\circ} \mathrm{C}$ sampai akan dilakukan elektroforesis, hasil akhir ini disebut isolat crude protein. Untuk mengetahui konsentrasi protein total setiap isolat dilakukan uji kuantitatif menggunakan spektrofotometri.

\section{Analisis profil protein spermatozoa}

Profil protein spermatozoa dianalisis berdasarkan berat molekul menggunakan Sodium Dodecyl Sulphate Poliacrylamide Gel Electrophoresis (SDS PAGE). (Laemmli, 1970) yang dilakukan dengan menggunakan metode standar. Sampel isolat protein dengan konsentrasi $70 \mu \mathrm{g} / \mu \mathrm{l}$ ditambahkan dengan $5 \mu \mathrm{l}$ buffer sampel, lalu dipanaskan pada suhu $50^{\circ} \mathrm{C}$ selama 2 menit. Kemudian didinginkan pada suhu ruang. Sampel dimasukkan ke dalam sumur gel dengan volume $25 \mu \mathrm{L}$, sedangkan volume marker protein yang digunakan sebanyak $5 \mu \mathrm{L}$. Running dilakukan pada tegangan $100 \mathrm{~V}, 48 \mathrm{~mA}$ selama 1-2 jam dalam buffer elektoforesis. Setelah running elektroforesis, gel diwarnai dengan menggunakan larutan pewarna (Coomassie Brilliant Blue) selama dua jam. Pelunturan warna (destaining) pada gel dilakukan dengan larutan peluntur secara berulang kali sampai diperoleh pita protein berwarna biru dengan latar gel bening

\section{HASIL DAN PEMBAHASAN}

Protein penanda (marker) pada penelitian ini menggunakan Chromatein Prestained Protein Ladder. Perhitungan jarak migrasi, nilai Rf, dan log BM protein marker dapat di lihat pada tabel berikut:

Tabel 1. Perhitungan Jarak Migrasi, Nilai Rf,dan Log BM Protein Marker

\begin{tabular}{|l|l|l|l|}
\hline $\begin{array}{l}\text { Berat Molekul } \\
(\mathbf{B M})(\mathbf{k D a})\end{array}$ & Jarak Migrasi & Nilai Rf & Log BM \\
\hline 175 & 0,14 & 0.0349 & 2.2430 \\
\hline 130 & 0,24 & 0.0603 & 2.1139 \\
\hline 95 & 0,4 & 0.0984 & 1.9777 \\
\hline 70 & 0,6 & 0.1524 & 1.8451 \\
\hline 62 & 0,9 & 0.2223 & 1.7924 \\
\hline 51 & 1,1 & 0.2826 & 1.7076 \\
\hline 42 & 1,4 & 0.3524 & 1.6232 \\
\hline
\end{tabular}


Setiyowati Putri Ayu I : Efek Pericarpium Manggis (Garcinia mangostana L.) Terhadap Protein Spermatozoa Epididimal Mencit Setelah Dipapar 2-Methoxyethanol

\begin{tabular}{|l|l|l|l|}
\hline 29 & 2,1 & 0.5169 & 1.4624 \\
\hline 22 & 2,8 & 0.7074 & 1.3422 \\
\hline 14 & 3,7 & 0.9265 & 1.1461 \\
\hline 10,5 & 3,9 & 0.9773 & 1.0212 \\
\hline
\end{tabular}

Hasil elektroforesis menunjukkan bahwa profil protein pada semua kelompok baik control maupun perlakukan mengekpresikan 8 pita protein dengan berat molekul: 90, 70, 62, 51, $42,35,27$, dan $22 \mathrm{kDa}$. Namun, pada kelompok perlakuan positif (K2) dan perlakuan polar dosis $2 \mathrm{mg} / \mathrm{kgBB}$ terdapat perbedaan, yaitu muncul protein dengan BM $27 \mathrm{kDa}$ (pada kelompok K2) dan $20 \mathrm{kDa}$ (pada kelompok P6) Hasil isolasi protein spermatozoa epididimal dengan menggunakan SDS-PAGE dapat di lihat pada Gambar 1 dan Gambar 2

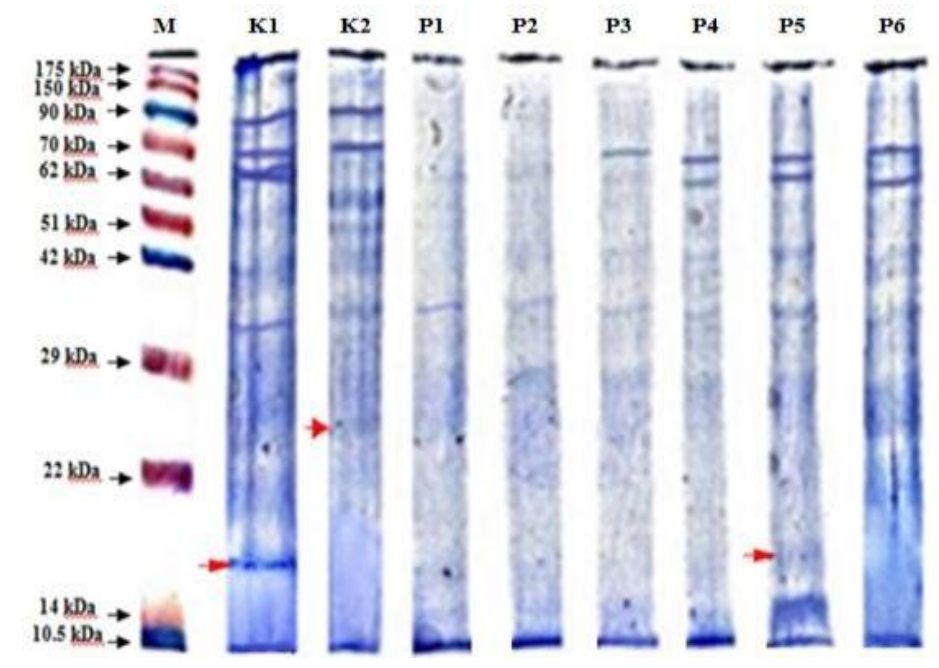

Gambar 1. Hasil isolasi protein spermatozoa epididimal diberi perlakuan ekstrak fraksi pericarpium manggis dengan variasi perlakuan kepolaran dan dosis ekstrak fraksi. $\mathrm{M}$ adalah marker dengan berat molekul 175 - 10,5 kDa, kontrol negatif (CMC 0,05\%) (K $\mathrm{K}_{1}$ ), kontrol positif (2-ME) $\left(\mathrm{K}_{2}\right)$, variasi perlakuan kepolaran dan dosis ekstrak fraksi yaitu: ekstrak fraksi n-heksan dengan dosis $0,6 \mathrm{mg} / \mathrm{kg}$ berat badan $\left(\mathrm{P}_{1}\right)$, ekstrak fraksi $\mathrm{n}$ - heksan dengan dosis $3 \mathrm{mg} / \mathrm{kg}$ berat badan $\left(\mathrm{P}_{2}\right)$, ekstrak fraksi etil asetat dengan dosis $4 \mathrm{mg} / \mathrm{kg}$ berat badan $\left(\mathrm{P}_{3}\right)$, ekstrak fraksi etil asetat dengan dosis $20 \mathrm{mg} / \mathrm{kg}$ berat badan $\left(\mathrm{P}_{4}\right)$, ekstrak fraksi methanol dengan dosis $0,4 \mathrm{mg} / \mathrm{kg}$ berat badan $\left(\mathrm{P}_{5}\right)$, ekstrak fraksi methanol dengan dosis $2 \mathrm{mg} / \mathrm{kg}$ berat badan $\left(\mathrm{P}_{6}\right)$. 
Setiyowati Putri Ayu I : Efek Pericarpium Manggis (Garcinia mangostana L.) Terhadap Protein Spermatozoa Epididimal Mencit Setelah Dipapar 2-Methoxyethanol

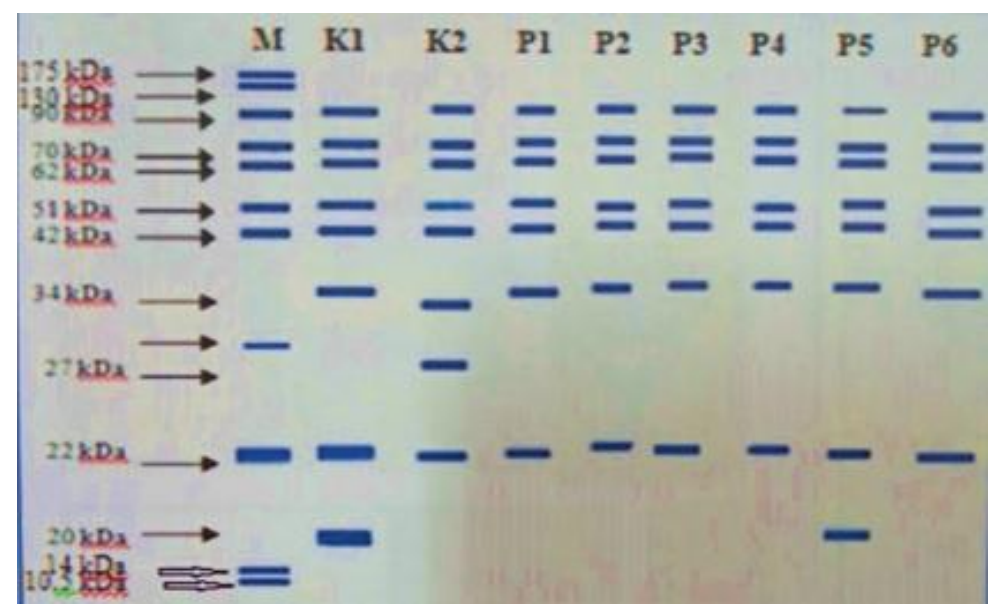

Gambar 2. Visualisasi representasi pita protein spermatozoa epididmal.

Hasil pengukuran pola pita protein pada elektroforesis diproses menggunakan software Paint Shop Pro 5 dan Adobe Photoshop CS 3 untuk memperoleh gambaran band-band protein secara lebih jelas dan data jarak migrasi pita protein yang nantinya akan digunakan untuk menghitung besarnya berat molekul protein yang berada di luar marker sehingga diperoleh data sebaran pola pita protein. Data sebaran pola pita protein disajikan pada tabel 2.

Tabel 2. Data sebaran pola pita protein

\begin{tabular}{|c|c|c|c|c|c|c|c|c|}
\hline \multirow{2}{*}{ 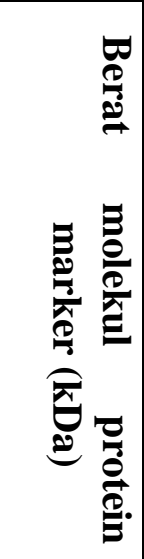 } & \multicolumn{8}{|c|}{ 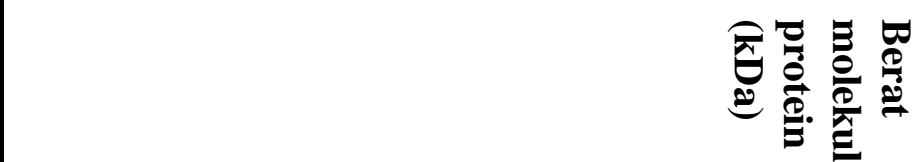 } \\
\hline & 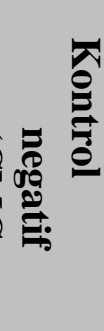 & 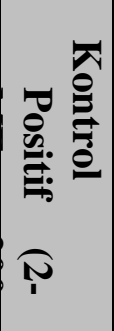 & 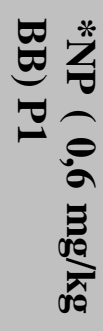 & 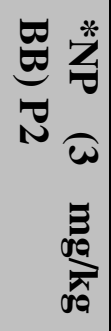 & 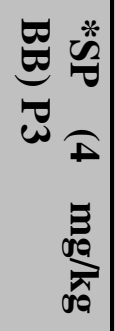 & 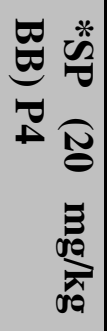 & 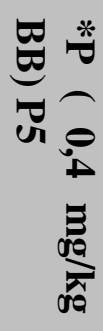 & 疍 \\
\hline 175 & - & - & - & - & - & - & - & - \\
\hline 130 & - & - & - & - & - & - & - & - \\
\hline 90 & \begin{tabular}{|l|}
90 \\
\end{tabular} & \begin{tabular}{|l|}
90 \\
\end{tabular} & 90 & 90 & 90 & 90 & 90 & 90 \\
\hline 70 & 70 & 70 & 70 & 70 & 70 & 70 & 70 & 70 \\
\hline 62 & 62 & 62 & 62 & 62 & 62 & 62 & 62 & 62 \\
\hline 51 & 51 & 51 & 51 & 51 & 51 & 51 & 51 & 51 \\
\hline 42 & 42 & 42 & 42 & 42 & 42 & 42 & 42 & 42 \\
\hline & 34 & 34 & 34 & 34 & 34 & 34 & 34 & 34 \\
\hline 29 & - & $\left.\right|^{-}$ & - & - & - & 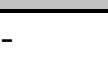 & - & - \\
\hline & - & 27 & - & - & - & - & - & - \\
\hline 22 & 22 & 22 & 22 & 22 & 22 & 22 & 22 & 22 \\
\hline 20 & 20 & 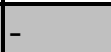 & - & - & & & 20 & - \\
\hline
\end{tabular}


Setiyowati Putri Ayu I : Efek Pericarpium Manggis (Garcinia mangostana L.) Terhadap Protein Spermatozoa Epididimal Mencit Setelah Dipapar 2-Methoxyethanol

$$
\begin{aligned}
& *=\text { Ekstrak Fraksi Pericarpium Manggis } \\
& \text { NP = Non Polar (N-heksan) } \\
& \text { SP = Semi Polar (Etil asetat) } \\
& \text { P = Polar (Methanol) }
\end{aligned}
$$

Profil protein dari sampel spermatozoa epididimal mencit, menunjukkan adanya beberapa pita protein dengan berat molekul (BM) berkisar antara 20-90 kDa. Secara umum, fungsi dari protein yang tereskpresi tersebut sebagai penentu keberhasilan terjadinya fertilisasi diantaranya :

1. Protein $90 \mathrm{kDa}$, sebagai proakrosin untuk pengikatan kelompok glikoprotein dari zona pelucida (Nagdas et al., 2014).

2. Protein $70 \mathrm{kDa}$, protein ini disintesis pada saat germ cell dan terekspresi pada membrane luar akrosom dan principal piece (Kim et al., 2010)., dikenal sebagai Het Shock Protein (HSP 70) yang berfungsi dalam motilitas spermatozoa (Han et al., 2011).

3. Protein 50-64 kDa, berperan saat fosforilasi tiroksin pada maturasi spermatozoa tikus (Fàbrega et al., 2011) serta penyusun tubulin $\alpha$ dan $\beta$ yang berperan pada pembentukan struktur flagella dan motilitas (El-Shahat et al., 2016).

4. Protein $42 \mathrm{kDa}$, sebagai protein protease yang berperan dalam penetrasi zona pelucida pada tikus (Hidayat et al., 2016) ; (Awda et al., 2009)

5. Protein 18-34 kDa, sebagai sperm protein (SP-10), merupakan protein spesifik yang terdapat di akrosom dan berfungsi untuk interaksi spermatozoa dengan ovum. Pada spermatozoa epididimal manusia, protein $34 \mathrm{kDa}$ merupakan protein $\mathrm{p} 34 \mathrm{H}$ (Arrotéia et al., 2011).

6. Protein $22-24 \mathrm{kDa}$, merupakan protein SP-17 yang berfungsi pada awal reaksi akrosom (Lea et al., 2004).

Protein spesifik yang hanya dapat terekspresi pada kelompok kontrol 2-ME $200 \mathrm{mg} / \mathrm{kg}$ berat badan yaitu protein dengan berat molekul $27 \mathrm{kDa}$, protein ini terekspresi spesifik diduga karena terjadi denaturasi protein pada kelompok kontrol ini, 2-ME merupakan kelompok senyawa oksidan kuat yang dapat menyebabkan stress oxidative, selian itu protein tersebut kemungkinan merupakan kelompok protein pelindung yang hadir ketika terjadi jejas pada sel fungsinya melindungi sel agar tetap pada keadaan homeostasisnya serta sedapat mungkin menjaga keberlangsungan proses sintesis protein pada sel. Pada penelitian ini dapat ditemukan protein dengan berat molekul $20 \mathrm{kDa}$, namun protein tersebut hanya dapat terekspresi pada kelompok kontrol CMC 0,05\% dan kelompok perlakuan fraksi polar dosis $0,4 \mathrm{mg} / \mathrm{kg}$ berat badan, diduga karena senyawa polar yang ada pada pericarpium manggis mengandung banyak senyawa yang mempunyai aktifitas farmakologi seperti flavonoida dan xanthone yang berfungsi sebagai antioksidan. Tidak terkespresinya protein dengan berat molekul rendah pada kontrol 2-ME $200 \mathrm{mg} / \mathrm{kg}$ berat badan diduga karena terjadi peningkatan ROS. Kadar ROS yang tinggi dapat menimbulkan kerusakan membran spermatozoa dan dapat berpengaruh pada kualitas spermatozoa. ROS yang meningkat akan menyerang polyunsaturated fatty acids (PUFA) sehingga menyebabkan terjadinya peroksidasi lipid pada membran spermatozoa (Agarwal \& Prabakaran, 2005). Penyebab tidak terekspresinya protein dengan berat molekul $20 \mathrm{kDa}$ pada fraksi polar dosis $2 \mathrm{mg} / \mathrm{kg}$ berat badan diduga karena terjadi peningkatan konsentrasi berlebih dari senyawa xanthon yang dapat menjadi oksidan. Berdasarkan penelitian dari (Moongkarndi et al., 2004), menunjukkan dua senyawa turunan xanthon yaitu senyawa mangostin ( $\alpha$ dan $\gamma$ ) serta garsinon- $E$ ektrak kulit buah manggis pada dosis tinggi dapat bersifat menjadi oksidan. Oksidasi pada protein menyebabkan kerusakan protein dan modifikasi protein serta asam amino. Tidak ada perbedaan jumlah ekspresi pita protein baik pada fraksi non polar dosis 
Setiyowati Putri Ayu I : Efek Pericarpium Manggis (Garcinia mangostana L.) Terhadap Protein Spermatozoa Epididimal Mencit Setelah Dipapar 2-Methoxyethanol

$0,6 \mathrm{mg} / \mathrm{kg}$ berat badan, fraksi non polar dosis $3 \mathrm{mg} / \mathrm{kg}$ berat badan, fraksi semi polar dosis 4 $\mathrm{mg} / \mathrm{kg}$ berat badan, dan fraksi semi polar dosis $20 \mathrm{mg} / \mathrm{kg}$ berat badan. Pelarut non polar ( $\mathrm{n}$ heksan) merupakan jenis pelarut yang dapat melarutkan beberapa senyawa kimia meliputi waxes, lemak, dan minyak. Kadar tanin yang semakin meningkat dapat menghambat sintesis protein spermatozoa pada bagian ekor (Rahmaningtyas et al., 2013). Selanjutnya untuk pelarut semi polar (etil asetat), pelarut ini dapat melarutkan beberapa senyawa kimia salah satunya yaitu alkaloid. Senyawa alkaloid terlarut bisa mengganggu aktifitas enzim ATP-ase pada membran sel spermatozoa dibagian tengah ekor. Jika aktivitas enzim ATP-ase terganggu, maka homeostasis ion natrium dan kalium akan terganggu sehingga dapat memicu terjadinya degradasi membran. Jika degradasi membran sel terjadi, diduga akan menyebabkan terdegradasinya komponen dalam membran sel yang penting seperti protein, DNA, dan akhirnya terjadi kematian sel (Weecharangsan et al., 2006). Pada penelitian ini mampu membuktikan bahwa ekstrak fraksi pericarpium manggis yang diketahui mengandung senyawa xanthon mampu memulihkan profil protein yang hilang akibat pemberian senyawa 2-ME.

\section{KESIMPULAN}

Pemberian ekstrak fraksi polar dengan dosis optimal yaitu $0,4 \mathrm{mg} / \mathrm{kg}$ berpengaruh terhadap profil protein epididimal spermatozoa mencit (Mus musculus). Terbukti degan terekspresi kembalinya beberapa protein yaitu protein dengan berat molekul $20 \mathrm{kDa}$ yang hilang akibat paparan senyawa 2-ME.

\section{DAFTAR PUSTAKA}

Agarwal, A., \& Prabakaran, S. A. (2005). Mechanism, measurement and prevention of O.S. Indian Journal of Experimental Biology, 43(November), 963-974.

Arrotéia, K. F., Garcia, P. V., \& Barbieri, M. F. (2011). The Epididymis : Embryology, Structure, Function and Its Role in Fertilization and Infertility.

Awda, B. J., Mackenzie-Bell, M., \& Buhr, M. M. (2009). Reactive Oxygen Species and Boar Sperm Function1. Biology of Reproduction, 81(3), 553-561. https://doi.org/10.1095/biolreprod.109.076471

El-Shahat, K. H., Taysser, M. I., Badr, M. R., \& Zaki, K. (2016). Effect of L-arginine treatment on motility, hyperactivity, acrosome reaction of ejaculated ram spermatozoa. Animal Reproduction, 13(2), 75-80. https://doi.org/10.21451/1984-3143-AR788

Fàbrega, A., Guyonnet, B., Dacheux, J. L., Gatti, J. L., Puigmulé, M., Bonet, S., \& Pinart, E. (2011). Expression, immunolocalization and processing of fertilins ADAM-1 and ADAM-2 in the boar (sus domesticus) spermatozoa during epididymal maturation. Reproductive Biology and Endocrinology, 9, 1-13. https://doi.org/10.1186/14777827-9-96

Fitri, R. A., Sumarmin, R., \& Yuniarti, E. (2017). BioScience|Volume 1 no. 1(2). https://doi.org/10.24036/bsc.v1i2.7718

Gaudreault, C., El Alfy, M., Légaré, C., \& Sullivan, R. (2001). Expression of the Hamster Sperm Protein P26h During Spermatogenesis1. Biology of Reproduction, 65(1), 7986. https://doi.org/10.1095/biolreprod65.1.79

Han, C., Park, I., Lee, B., Jin, S., Choi, H., Kwon, J. T., Kwon, Y. il, Kim, D. H., Park, Z. Y., \& Cho, C. (2011). Identification of heat shock protein 5, calnexin and integral membrane protein 2B as Adam7-interacting membrane proteins in mouse sperm. Journal of Cellular Physiology, 226(5), 1186-1195. https://doi.org/10.1002/jcp.22444

Hidayat, E., Susanti, R., \& Marianti, A. (2016). Protein Profile and Mda Spermatozoa Levels of Hyperglycemic Mice Fed By Bean Sprouts Extract. Indonesian Journal of Pharmacy, 26(4), 192. https://doi.org/10.14499/indonesianjpharm26iss4pp192 
Setiyowati Putri Ayu I : Efek Pericarpium Manggis (Garcinia mangostana L.) Terhadap Protein Spermatozoa Epididimal Mencit Setelah Dipapar 2-Methoxyethanol

Kim, E., Lee, J. W., Baek, D. C., Lee, S. R., Kim, M. S., Kim, S. H., Kim, C. S., Ryoo, Z. Y., Kang, H. S., \& Chang, K. T. (2010). Processing and subcellular localization of ADAM2 in the Macaca fascicularis testis and sperm. Animal Reproduction Science, 117(1-2), 155-159. https://doi.org/10.1016/j.anireprosci.2009.04.002

Kurniawati, M., Mahdi, C., \& Aulanni'am, A. (2014). The Effect Of Juice Mangosteen Rind (Garcinia Mangostana L.) To Blood Sugar Levels And Histological Of Pancreatic Rats With The Induction Of Streptozotocin. The Journal of Pure and Applied Chemistry Research, 3(1), 1-6. https://doi.org/10.21776/ub.jpacr.2014.003.01.145

Lea, I. A., Widgren, E. E., \& O'Rand, M. G. (2004). Association of sperm protein 17 with A-kinase anchoring protein 3 flagella. Reproductive Biology and Endocrinology, 2, 17. https://doi.org/10.1186/1477-7827-2-57

Mahasri, G., Fajriah, U., \& SUBEKTI, S. (2010). Karakterisasi protein Lernaea cyprinacea dengan Metode Elektroforesis SDS-PAGE. Jurnal Ilmiah Perikanan Dan Kelautan, 2(1), 61-67.

Moongkarndi, P., Kosem, N., Kaslungka, S., Luanratana, O., Pongpan, N., \& Neungton, N. (2004). Antiproliferation, antioxidation and induction of apoptosis by Garcinia mangostana (mangosteen) on SKBR3 human breast cancer cell line. Journal of Ethnopharmacology, 90(1), 161-166. https://doi.org/10.1016/j.jep.2003.09.048

Nagdas, S. K., McLean, E. L., Richardson, L. P., \& Raychoudhury, S. (2014). Identification and characterization of TEX101 in bovine epididymal spermatozoa. Biochemistry Research International, 2014. https://doi.org/10.1155/2014/573293

Rahmaningtyas, E., Yusa, N. M., \& Puspawati2, N. N. (2013). Pengaruh penambahan cmc (. Teknologi Pertanian Universitas Udayana, 34(1), 1-7. https://ojs.unud.ac.id/index.php/itepa/article/download/27494/17403/.

Starek-wiechowicz, B., Szymczak, W., Budziszewska, B., \& Starek, A. (2015). Testicular effect of a mixture of 2-methoxyethanol and 2-ethoxyethanol in rats. Pharmacological Reports, 67(2), 289-293. https://doi.org/10.1016/j.pharep.2014.09.011

Weecharangsan, W., Opanasopit, P., Sukma, M., Ngawhirunpat, T., Sotanaphun, U., \& Siripong, P. (2006). Antioxidative and neuroprotective activities of extracts from the fruit hull of mangosteen (Garcinia mangostana Linn.). Medical Principles and Practice, 15(4), 281-287. https://doi.org/10.1159/000092991

\begin{tabular}{|l|l|l|l|}
\hline Accepted Date & Revised Date & Decided Date & Accepted to Publish \\
\hline 06 Agustus 2020 & 08 Agustus 2020 & 11 Agustus 2020 & Ya \\
\hline
\end{tabular}

